\title{
PERAN CHIEF INFORMATION OFFICER DALAM KELEMBAGAAN TEKNOLOGI INFORMASI DAN KOMUNIKASI PADA PEMERINTAH KOTA DEPOK
}

\author{
Syarif Budhirianto \\ Balai Pengkajian dan Pengembangan Komunikasi dan Informatika (BPPKI) Bandung \\ Jl. Pajajaran No. 88 Bandung 40173, Telp. (022) 6017493 \\ Naskah diterima tanggal 30 September 2012, disetujui tanggal 22 November 2012
}

\begin{abstract}
ROLE OF THE CHIEF INFORMATION OFFICER IN INSTITUTIONAL INFORMATION AND COMMUNICATION TECHNOLOGY IN THE CITY DEPOK
\end{abstract}

\begin{abstract}
Chief Information Officer (CIO) is a title given to someone in the government agencies that has a responsibility of developing the concept of governance in the field of ICT. In this position the $\mathrm{CIO}$ acts as the agent of change that establishes the planning, policy, and evaluate a variety of programs related to the implementation of ICT. The study was conducted in Depok City Government through explorative study approach, technical focus group discussion (FGD) within the Office of the Regional Secretariat of Communication and Information and Public Relations field. The results of the study is the role of the CIO needs to be placed at a strategic level a notch below the regional secretary to accommodate all the interests of the organization of the regions, the role of ICT program planning and executioner placed at the level of the Regional Planning Agency and the departments / regional technical institutions. While the CIO position should have the competence, objectivity and accountability, in accordance with the standards of technical competence, ICT management and coordination functions / communications.
\end{abstract}

Keywords: Chief Information Officer, ICT governance, institutional Information and Communication Technology.

\begin{abstract}
Abstrak
Chief Information officer (CIO) merupakan suatu jabatan yang diberikan kepada seseorang dalam lembaga pemerintahan yang memiliki tanggung jawab mengembangkan konsep tata kelola di bidang Teknologi Informasi dan Komunikasi (TIK). Dalam posisi ini CIO berperan sebagai agent of change yang menetapkan perencanaan, kebijakan, serta mengevaluasi berbagai program yang terkait dengan implementasi TIK. Penelitian ini dilaksanakan pada Pemerintah Kota Depok melalui pendekatan studi eksploratif (exploratory studies), melalui focus group discussion (FGD) dilingkungan Dinas Kominfo dan Sekretariat Daerah Bidang Kehumasan. Hasil penelitian adalah peran CIO perlu ditempatkan pada level strategis setingkat di bawah Sekretaris Daerah yang dapat mengakomodasi seluruh kepentingan OPD, peran perencanaan program-program TIK serta eksekutor ditempatkan pada level Badan Perencanaan Daerah dan dinas/lembaga teknis daerah. Sedangkan kompetensi jabatan CIO harus memiliki objektivitas
\end{abstract}


dan akuntabilitas yang baik, sesuai dengan standar kompetensi teknis, manajemen TIK dan fungsi koordinasi/komunikasi.

Kata Kunci: Chief Information Officer, tata kelola TIK, kelembagaan Teknologi dan Informasi.

\section{PENDAHULUAN}

Keberadaan Teknologi Informasi dan Komunikasi (TIK) di instansi pemerintah daerah tidak dapat dihindarkan lagi, terutama dalam mendukung pelayanan publik lebih efektif dan efisien. Tetapi dalam perkembangannya masing-masing Organisasi Perangkat Daerah (OPD) belum memiliki pemahaman secara komprehensif tentang esensi TIK dalam membangun TIK yang lebih terkoordinasi dan terintegrasi.

Faktor yang menjadi fokus perhatian dalam pengembangan TIK, yaitu dengan penataan kelembagaan di bidang TIK, di mana peran dan tanggung jawab kewenangannya berada pada level jabatan Chief Information Officer (CIO) dalam menetapkan kebijakan dan evaluasi implementasi di setiap OPD. Hanna \& Qiang (2007) menyatakan, pemerintah dan stakeholder lainnya harus mampu: mengintegrasikan dengan arah pembangunan pemerintah secara umum, menyinergikan dengan infrastruktur yang ada, mengoordinasikan dengan komponen $e$ government yang ada, mengoptimalkan perencanaan terkait dengan pembagian wewenang sentralisasi atau desentralisasi, menyesuaikan dengan kemampuan dan arsitektur kelembagaan (Nupikso,2010).

Peran CIO pada setiap instansi pemerintah, menjadi penting karena keberadaannya sangat strategis dalam menyinergikan pemanfaatan TIK serta sebagai media konsultasi pada masing-masing OPD.

Dalam implementasinya dibutuhkan konsep TIK yang terpola, yang berfungsi sebagai enabler menuju keadaan yang lebih baik. Dalam konteks pemerintahan, perlu adanya tujuan dan sistem birokrasi yang jelas sebagai syarat pengefektifan, karena peranan CIO beserta staf lain berfungsi sebagai information officer (IO) atau agent of change.
Persoalan yang dihadapi sekarang adalah eksistensi jabatan CIO secara kelembagaan di tiap OPD belum optimal diberdayakan, padahal untuk memainkan perannya perlu tata kelola TIK dalam suatu frame work untuk lebih memperkuat penetrasi TIK, yakni melalui fungsi-fungsi organisasi yang sudah ada.

Kota Depok sebagai penyangga ibu kota negara yang mempunyai peringkat tertinggi di Provinsi Jawa Barat pada bidang electronic government (e-government) selayaknya menjadi agen perubahan bagi daerah lainnya. Dengan mengedepankan peran CIO dalam sistem penataan kelembagaan yang ada dan dengan semangat reformasi birokrasi, maka layanan publik berbasis TIK akan mendorong tata kelola pemerintahan yang baik (good governance), sesuai dengan visinya, yaitu Depok Cyber City.

yang dipaparkan, masalah penelitian dikemukakan sebagai berikut: bagaimana peran dari CIO dalam kelembagaan TIK di Pemerintah Kota Depok, identifikasi masalah penelitian ini adalah, 1) Bagaimana penataan kelembagaan jabatan CIO pada OPD Kota Depok; 2) Bagaimana peran dan fungsinya dalam mengembangkan TIK; 3) Bagaimana kompetensi dan tata kelola (frame work) CIO dalam pengembangan program TIK.

Tujuan penelitian adalah untuk mengetahui penataan kelembagaan jabatan CIO pada OPD Kota Depok yang sesuai dengan peran dan fungsi bidang TIK, serta kompetensi dan tata kelola $C I O$ dalam pengembangan program TIK. Sedangkan kegunaan penelitian ini adalah sebagai masukan Komunikasi dan Informatika (Kemenkominfo) dalam membuat kebijakan tentang model penataan kelembagaan jabatan CIO serta membuat framework tata kelola kelembagaan TIK di OPD kabupaten atau kota, sehingga seorang $\mathrm{CIO}$ dapat 
melaksanakan tugas dan fungsinya secara optimal.

\section{LANDASAN KONSEP}

Penelitian ini berangkat dari pola penataan kelembagaan dalam mengimplementasikan peran dan fungsi jabatan CIO di organisasi perangkat daerah (OPD) Kota Depok, di mana mempunyai pengelompokan jabatan TIK tertinggi sampai terendah yang saling berhubungan dan dikerjakan bersama. Dalam proses aktivitas, memiliki tugas dan tanggung jawab sesuai dengan uraian jabatan (job description), harapannya agar sumber daya manusia (SDM) sebagai enabler dibidang TIK bertanggung jawab dalam melaksanakan tugas.

Namun dari dinamika organisasi, secara empirik tata pengelolaan organisasi pemerintahan perlu pengadaptasian dengan pola strategis baru, yakni dengan mengakomodasi perkembangan teknologi informasi komunikasi (TIK). Untuk menghadapi perkembangannya yang begitu cepat, maka peran kelembagaan di pemerintahan perlu strategi tata kelola (frame work) organisasi, baik dari sisi pemberdayaan fungsi jabatan maupun mengoptimalkan pengembangan TIK yang selama ini berjalan.

Chief Information Officer (CIO) merupakan suatu jabatan yang diberikan kepada seseorang dalam suatu organisasi atau pemerintahan yang memiliki tanggung jawab pada teknologi informasi dan sistem komputer dalam mendukung tujuannya. Dengan peran sistem informasi dan teknologi informasi yang menjadi semakin penting, CIO adalah sebagai salah satu pemberi kontribusi utama dalam memformulasikan strategi untuk pencapaian tujuan dari organisasi.

\section{Peran CIO dalam Konteks Kelembagaan CIO Dalam Organisasi Pemerintahan}

Forum Asia Pacific Cooperation Telecomunication and Information Working Group (APECTEL) mendefinisikan peran
CIO ke dalam dua poin besar, yakni enterprise leadership in information and IT management and provision to support future projects for competitive business value, dan management of daily delivery of IT/IS services (Darono:2011). Definisi tersebut, dalam konteks kelembagan pemerintah di lingkungan pemerintah daerah, enterprise leadership diterjemahkan sebagai kepemimpinan yang mencakup struktur perangkat daerah yang mutlak dilakukan dengan kondisi dan kebutuhan pemerintah kabupaten/kota. Hanya saja, penyediaan informasi dan TIK harus ditempatkan dalam kerangka tugas lembaga pemerintah sebagai penyelenggara layanan publik.

Implementasi TIK yang efektif memerlukan perubahan pada aspek-aspek lain, serta penyelarasan tujuan dan sistem birokrasi. Dalam posisi inilah, CIO dan staf lain berperan sebagai information officers (IO) memegang peranan penting sebagai agent of change, menetapkan arahan dan kebijakan dan merencanakan, mengeksekusi, serta mengevaluasi berbagai program yang terkait dengan implementasi TIK. Untuk merinci implementasi yang diperankan oleh CIO, Magister Teknik Informasi (MTI) UGM merumuskannya sebagai berikut (www.mti.ugm.ac.id) :

1. Penyusun strategi TIK, dalam tahap awal pembangunan e-government (Inpres $3 / 2003$, tentang Kebijakan dan Strategi Nasional Pengembangan E-Government) harus bisa melahirkan transformasi relasi antara pemerintah dengan warga, pemerintah dengan dunia usaha dan sesama lembaga pemerintah. Untuk mencapat tujuan tersebut, pemda memerlukan visi, misi dan strategi pemanfaatan TIK.

2. Penyelarasan proses birokrasi, TIK sebagai enabler harus berjalan seiring dengan birokrasi yang ada, dimana proses birokrasi sekarang tidak kondusif bagi pemanfaatan TIK secara optimal. Sehingga perlu pendekatan secara top down (struktur, mekanisme kerja, tupoksi dsb.) peran dari CIO pada posisi strategis sebagai promotor dan inisiator bagi penyelarasan ini. 
3. Promotor manajemen, seorang CIO harus dapat melihat bagaimana TIK memberikan solusi dan dapat mendefinisikan tujuan dan sasaran yang akan diimplementasikan, strategi pengembangan dan operasionalisasinya dan tahapan-tahapan selanjutnya.

4. Penentu kebutuhan TIK, penentuan kebutuhan dengan memanfaatkan prinsip efisiensi dan efektivitas (fasilitas TIK) perlu dilakukan CIO, lingkupnya adalah pada seluruh kabupaten dan kota, sehingga perlu memperhitungkan alokasi dan pemakaian bersama di lembagalembaga yang ada.

5. Perancang anggaran TIK, CIO perlu memiliki fungsi perancang anggaran untuk menjamin kebutuhan TIK secara tepat guna.

6. Pengelola operasional sistem TIK, diperlukan untuk menjamin operasional sistem TIK dapat berjalan dengan baik.

7. Penilai kinerja TIK, untuk mengetahui kelayakan implementasi dengan anggaran, evaluasi kenerja dapat memberitahu aspek-aspek apa saja yang perlu mendapatkan perhatian $\mathrm{CIO}$.

Ketujuh peran tersebut tidak dijalankan oleh satu jenis CIO saja, ada peran yang memerlukan kekuatan struktural pada level strategik, ada peran yang memerlukan kapabilitas koordinasi fungsional, dan ada peran yang memerlukan kapabilitas teknis operasional. Berdasarkan pada manajemen pengorganisasian tersebut, maka landasan atau kerangka pemikiran penelitian, dapat digambarkan pada Gambar 1.

\section{Tugas Government CIO dan Landasan} Hukum

Untuk mencapai tujuan organisasi, Government CIO (G-CIO) berperan sebagai pemimpin penyediaan informasi melalui pemanfaatan TIK dan aspek-aspek manajemen lainnya. Pada tiap internal organisasi, tugas $\mathrm{G}-\mathrm{CIO}$ adalah mengoordinasikan, merencanakan, merealisa-

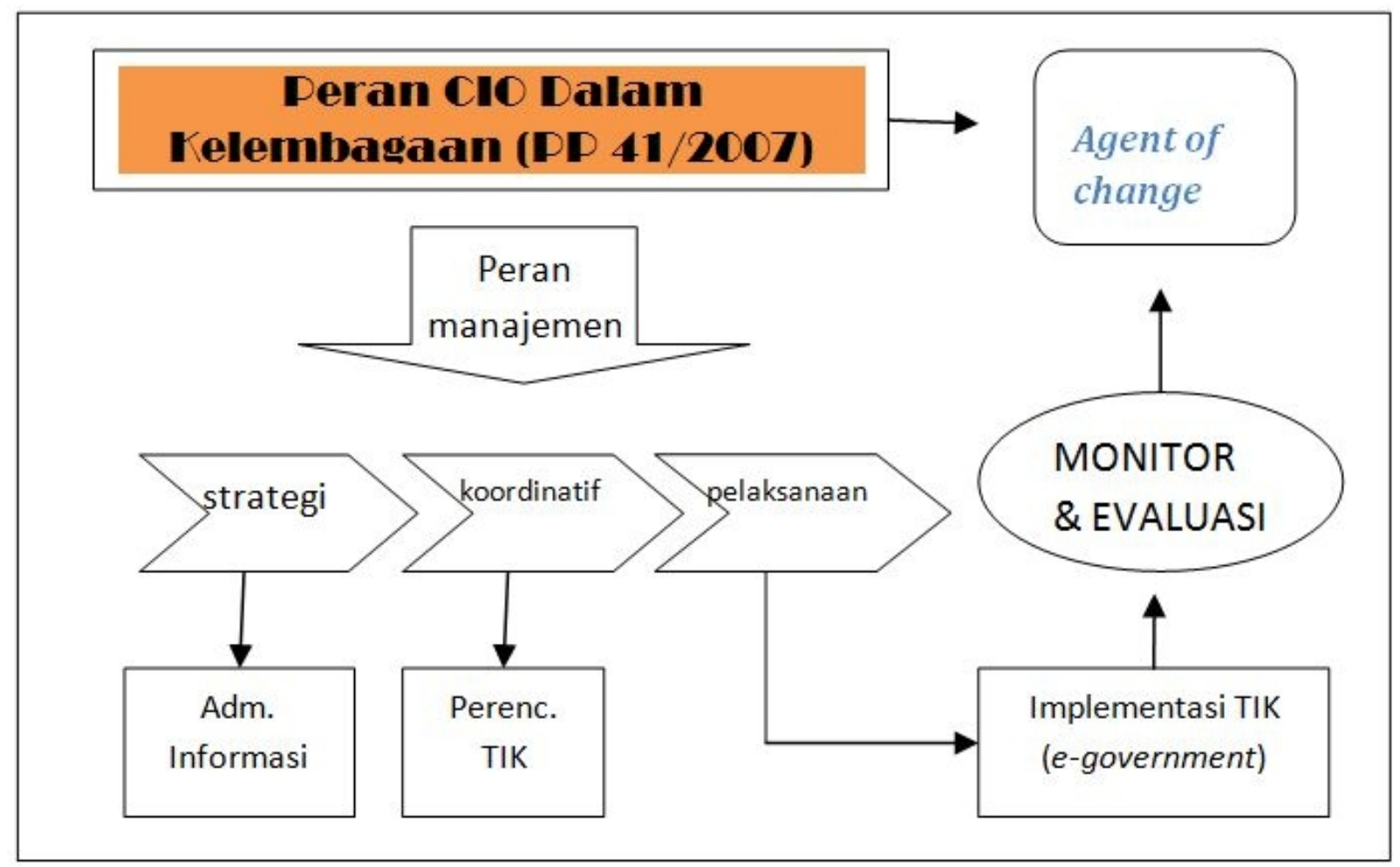

Gambar 1

Kerangka Pikir Peran CIO Dalam Penataan Kelembagaan di Pemerintah Daerah 


\section{Tabel 1}

Landasan Hukum Pemanfaatan TIK

Dasar Hukum

Inpres No. 3 tahun 2003

Peraturan Menkominfo No.41/11/2007

PP 41 tahun 2007 tentang Organisasi Perangkat Daerah

UU No. 11 tahun 2008 tentang Informasi Dan Transaksi Elektronik pasal 4.

UU No. 14 Tahun 2008, Tentang Keterbukaan Informasi Publik
Tentang kebijakan dan strategi nasional pengembangan e-government.

Tentang Panduan Umum Tata Kelola TIK: a) pembentukan CIO dan Komite TIK di tiap institusi pemerintah merupakan prioritas. b) hierarki struktur tata kelola tentang CIO bertugas mengoordinasi, perencanaan, operasional dan evaluasi TI.

a.Ayat 1, pembentukan organisasi perangkat daerah ditetapkan dengan perda dengan berpedoman PP

b. Ayat 2 perda yang mengatur susunan, kedudukan, tugas pokok organisasi perangkat daerah.

c.Ayat 3, rincian tugas, fungsi, yang diatur lebih lanjut dengan peraturan gubernur/bupati/walikota.

Pemanfaatan teknologi informasi dan transaksi elektronik dilaksanakan dengan tujuan untuk meningkatkan efektivitas dan efisiensi pelayanan publik.

Pasal 13, Badan publik membentuk Pejabat Pengelola Informasi dan Dokumentasi (PPID), melalui Keputusan Menkominfo Nomor 117/2010.

Sumber: Panduan Umum Tata Kelola TIK, 2007: 35

sikan, mengoperasionalkan, dan mengevaluasi TIK. Tugas tersebut dilaksanakan dengan melibatkan kerjasama antar satuan kerja dan pengguna TIK lainnya, sehingga peran TIK dalam suatu organisasi dapat dimanfaatkan secara maksimal, yakni :

a. TIK sebagai support, yang mendukung jalannya organisasi dan otomatisasi dari back office sebuah organisasi dan menjadikan pelengkap dari suatu pemerintahan.

b. TIK sebagai enabler, sebagai penggerak dan kekuatan utama dalam suatu organisasi.

c. TIK sebagai driver, sebagai sarana untuk mengembangkan layanan, dimana dengan kapabilitas TI yang dimiliki, sebuah organisasi/perusahaan dapat melakukan ekspansi pasar/layanan.

d. TIK sebagai transformer, berfungsi untuk menentukan arah aktivitas organisasi/ bisnis. (Haryadi Dalam Supangkat, 2008)

Adapun landasan hukum implementasi tentang urgensinya pemanfaatan TIK yang dibentuk melalu G-CIO, bertumpu pada beberapa peraturan perundang-undangan, seperti tercantum pada Tabel 1 .

\section{CIO dan Tata Kelola TIK}

Fungsi CIO dalam tata kelola TIK merupakan sebuah framework yang menghubungkan berbagai aspek bisnis, strategi organisasi terhadap pengaturan tata kelola. Agar dapat berjalan dengan efisien diperlukan keahlian seorang $\mathrm{CIO}$ dalam mengharmonisasikan strategi organisasi terhadap mekanisme IT Governance.

Fokus utama seorang $\mathrm{CIO}$ dalam menjalankan tugasnya adalah membangun dan mengimplementasikan tata kelola TIK. Hal ini 
karena adanya tata kelola TIK yang baik dapat membantu organisasi/perusahaan dalam membuat keputusan.

Dengan peran CIO tersebut, keberadaan tata kelola TIK tidak lepas dari urgensi tata kelola organisasi atau pemerintahan, dimana secara konseptual corporate governance pada dasarnya adalah sekumpulan kriteria dan tools yang diperlukan untuk memastikan value creation yang konsisten secara berkelanjutan serta menjamin efektivitas strategi dan efisiensi operasional pada organisasi.

\section{Eksistensi CIO dalam Manajemen Organisasi}

Perkembangan TIK memengaruhi konsep dan implementasi strategi dalam organisasi. Sejalan dengan perubahan keberadaan fungsi TIK dari level operasional menjadi strategis di beberapa organisasi, muncul satu fungsi manajerial baru yaitu CIO. Wheelen dan Hunger (2004), memandang manajemen strategi adalah sebagai perkembangan lebih lanjut dari kebijakan organisasi, sedangkan Hunton (2004) lebih cenderung menggunakan istilah strategic planning, yaitu suatu proses sebagai panduan utama untuk mengalokasikan sumber daya di seluruh organisasi dan tetap menjaga dalam kondisi yang terbaik.

Perbedaan kedua pendapat ini adalah kebijakan bisnis lebih kepada kegiatan manajerial umum yang berorientasi dan cenderung melihat ke sisi internal organisasi dengan tujuan untuk mengintegrasikan semua aktivitas manajerial yang ada. Sementara itu, manajemen strategi merupakan serangkaian keputusan dan tindakan manajerial yang menentukan kinerja dalam jangka panjang. Jadi menurut pandangan ini, manajemen strategis mempunyai cakupan yang lebih luas dari kebijakan bisnis.

Sejalan dengan perubahan keberadaan fungsi TIK dari level operasional menjadi strategis di beberapa level organisasi, maka fungsi CIO, Mc Leod dan Schell (2004) menyatakan hubungan antara manajemen strategi dengan istilah strategic planning for information resources, menyatakan kedudukan strategi CIO adalah (1) memberikan arah strategis bagi sumber daya informasi; (2) mengoordinasikan sistem informasi (SI) dengan strategi perencanaan organisasi keseluruhan. Lebih lanjut, Keen (1991, dalam Frenzel, 2006) menyatakan bahwa CIO adalah lebih menekankan pada pengertian hubungan (relationship), bukanlah jabatan (job), sementara dari kalangan CIO sendiri berdasarkan survei yang dilakukan Institute for Business Value (IBM), menyimpulkan bahwa keberadaan CIO adalah: makes innovation real, raises the ROI of IT, expands business impact.

Selanjutnya, Wheelen dan Hunger, menguraikan manfaat dari penerapan manajemen TIK dalam organisasi, yakni: pemahaman yang lebih baik pada visinya, meningkatkan pemahaman akan situasi yang terus berubah dengan cepat, sehingga dengan demikian terdapat tiga pertanyaan kunci strategis yang harus dijawab oleh organisasi: (1) di manakah organisasi sekarang.; (2) jika tidak ada perubahan yang di buat, di manakah organisasi berada dalam satu, dua, lima atau sepuluh tahun? Apakah jawaban dapat diterima?; (3) jika jawaban tidak diterima, apa tindakan spesifik yang harus manajemen lakukan?. Sedangkan menurut Davenport (1992), hanya jika pemanfaatan TIK diperlakukan sebagai bagian yang utuh dari organisasi, maka cita-cita untuk menuju orgnisasi berbasis informasi dapat dicapai. Namun, kenyataannya, sampai kini dalam implementasinya, para pemilik informasi penting di lembaga birokrat ternyata belum melaksanakan, baik secara terang-terangan maupun berlindung dibalik manuver birokrasi.

Situasi tersebut, persis seperti yang terjadi pada posisi $\mathrm{CIO}$ di tingkat pemerintah daerah yang belum jelas pada struktur organisasi dan tata kerja (STOK), pembagian lahan kerja antara bagian kehumasan dan Kominfo. Hal ini lebih banyak disebabkan oleh komitmen konsesi antara siapa yang membangun teknologi informasi dan komunikasi, sehingga sistem yang memungkinkan harapan pemerintah daerah dapat diterjemahkan, begitu pula siapa yang harus mengelola dan mengoordinasikannya.

Sebenarnya, istilah CIO ini lebih pada 
penamaan yang bersifat umum, karena dalam praktiknya akan ditemui berbagai nama lain, misalnya vice Presiden of Information System, IS Resources Manager, Senior IT Executive. Semuanya itu keberadaannya/eksistensi dalam suatu organisasi biasanya sangat terkait dengan perencanaan strategis sumber daya informasi, artinya sampai dengan tingkat tertentu keberadaan fungsi CIO dapat menunjukkan seberapa strategis kedudukan TIK dalam organisasi. Dalam beberapa kasus, keberadaannya telah berada di garda depan perubahan untuk menuju situasi terbaik dalam organisasi.

\section{Peran Pengorganisasian}

Pengorganisasian merupakan proses penyusunan struktur organisasi yang sesuai dengan tujuan organisasi, sumber daya yang dimiliki, dan ruang lingkup lingkungan. Dua aspek utama proses susunan struktur organisasi yaitu departementalisasi dan pembagian kerja. (http://passiriograzio.blogspot.com)

Departementalisasi adalah pengelompokkan kegiatan kerja organisasi agar kegiatan-kegiatan sejenis saling berhubungan dan dapat dikerjakan bersama. Hal ini akan tercermin pada struktur formal suatu organisasi dan tampak atau ditunjukkan oleh bagan suatu organisasi. Bagan/struktur organisasi biasanya dibagi menjadi beberapa jabatan, dan pada setiap jabatan memiliki tugas, tanggung jawab, wewenang, dan uraian jabatan (job description). Semakin tinggi suatu jabatan semakin berat beban tugas, tanggung jawab, dan wewenangnya. Namun, biasanya hal ini diiringi dengan semakin besarnya penghasilan yang didapatkan.

Dengan pembagian tugas tersebut, tujuan organisasi dapat menjadi lebih mudah untuk dicapai. Peran penting dari manajemen dalam hal ini adalah kemampuan dalam pembagian tugas yang sesuai dengan keahliannya masing-masing. Pembagian kerja adalah perincian tugas pekerjaan agar setiap individu pada organisasi bertanggung jawab dalam melaksanakan sekumpulan kegiatan. Kedua aspek ini merupakan dasar proses pengorganisasian suatu organisasi.
Untuk mencapai tujuan yang telah ditetapkan secara efisien dan efektif, ada beberapa pengertian organisasi, antara lain :

1. Cara menajemen merancang struktur formal untuk pengunaan yang paling efektif sumber daya yang ada.

2. Bagaimana organisasi mengelompokkan kegiatan-kegiatannya, dan pada tiap kelompok diikuti dengan penugasan seorang manajer yang diberi wewenang untuk mengawasi anggota-anggota kelompok.

3. Hubungan-hubungan antara fungsi-fungsi, jabatan, tugas.

4. Cara para manajer membagi tugas yang harus dilaksanakan dalam departemen mereka dan mendelegasikan wewenang yang diperlukan dalam pelaksanaan tugas tersebut.

Ada beberapa aspek penting dalam proses pengorganisasian, yaitu bagan organisasi formal, pembagian kerja, departementalisasi, rantai perintah atau kesatuan perintah, tingkat-tingkat hirarki manajemen, saluran komunikasi, dan rentang manajemen dan kelompok informal yang dapat dihindarkan. Proses pengorganisasian terdiri dari tiga tahap, yaitu :

1. Perincian seluruh pekerjaan yang harus dilaksanakan setiap individu dalam mencapai tujuan organisasi.

2. Pembagian beban pekerjaan menjadi kegiatan yang secara logika dapat dilaksanakan oleh setiap individu. Pembagian kerja sebaiknya tidak terlalu berat sehingga tidak dapat diselesaikan, atau terlalu ringan sehingga ada waktu menganggur, tidak efisien dan terjadi biaya yang tidak perlu.

3. Pengadaan dan pengembangan mekanisme kerja sehingga ada koordinasi pekerjaan para anggota organisasi menjadi kesatuan yang terpadu dan harmonis. (http://passiriograzio.blogspot.com)

\section{METODE PENELITIAN}

Penelitian ini bersifat kualitatif, dengan menggunakan pendekatan eksploratif 
(exploratory studies), yakni dengan menghimpun dan mengumpulkan informasi aktual dari para pejabat struktural dan staf dibidang TIK di lingkungan Satuan Kerja Perangkat Daerah (SKPD) Diskominfo serta di Sekretariat Daerah Bidang Kehumasan Pemerintah Kota Depok. Teknisnya dengan cara Focus Group Discussion (FGD), yakni dengan proses pengumpulan informasi mengenai suatu permasalahan tertentu yang sangat fokus dan spesifik melalui diskusi kelompok (Hariwijaya, 2007).

Pengumpulan data lainnya adalah dengan penelaahan dokumen yang berhubungan dengan penelitian ini, baik dari catatan/buku, arsip-arsip, dan sejenisnya, termasuk laporan yang tersedia pada objek penelitian, juga memanfaatkan dokumen pada satuan organisasi tata kerja (SOTK) pada kedua OPD.

Teknik analisis data dalam penelitian kualitatif terdiri dari tiga alur kegiatan yang terjadi bersamaan, yaitu reduksi data, penyajian data, dan penarikan kesimpulan/verifikasi (Miles dan Huberman dalam Ardianto, 2010). Reduksi adalah proses pemilihan perhatian pada penyederhanaan, dan transformasi data kasar dari hasil eksploratif di lapangan atau secara dokumentatif selama penelitian yang berorientasi kualitatif dapat disederhanakan dan ditransformasikan melalui seleksi ketat, melalui ringkasan, mengggolongkannya dalam satu pola yang lebih luas, dan sebagainya.

Penyajian data sebagai alur penting dari analisis data ini adalah sebagai penyajian sekumpulan informasi yang tersusun yang memberi kemungkinan adanya penarikan kesimpulan dan pengambilan tindakan. Penyajian meliputi pula berbagai jenis matriks, grafik, jaringan, dan bagan.

\section{HASIL PENELITIAN DAN PEMBAHASAN}

\section{Tingkat Penerapan Bidang TIK Pemerintah Kota Depok}

$$
\text { Upaya membangun teknologi }
$$

informasi dan komunikasi (TIK) yang optimal adalah dengan memperhatikan peran dan fungsi kelembagaan, serta sistem tata kelola yang baik, karena faktor ini sangat urgen yang dapat memengaruhi keseluruhan aktivitas. Hanna \& Qiang menyatakan struktur kelembagaan harus mampu dan melakukan fungsi sebagai:

1. Mengintegrasikan dengan arah pembangunan pemerintah secara umum.

2. Menyinergikan dengan infrastruktur yang ada.

3. Mengoordinasikan dengan komponen TIK yang ada

4. Mengoptimalkan perencanaan terkait dengan pembagian wewenang sentralisasi atau desentralisasi.

5. Menyesuaikan dengan kemampuan dan arsitektur kelembagaan. (dalam Nupikso, 2010)

Pengembangan dan penataan kelembagaan yang dilakukan di lingkungan organisasi perangkat daerah (OPD) telah mengubah Pemerintah Kota Depok dan menyelaraskan dengan Peraturan Pemerintah Nomor 41 Tahun 2007, tentang Organisasi Perangkat Daerah (OPD). Pemerintah Kota Depok sendiri, dalam memperluas ruang lingkup kinerja serta dalam mewujudkan visi dan misinya. Sejak Januari 2012 Dinas Komunikasi dan Informasi berganti nama menjadi Dinas Komunikasi dan Informatika, hal ini perkuat dengan Peraturan Daerah Nomor 20 Tahun 2011 tanggal 29 Desember 2011 Tentang Perubahan Kedua Atas Perda No. 8 Tahun 2008 tentang OPD, serta Peraturan Walikota Depok Nomor 56 Tahun 2011 Tentang Rincian Tugas, Fungsi dan Tata Kerja Dinas Komunikasi dan Informatika.

Perubahan dan penataan organisasi tersebut merupakan hal biasa dan sudah beberapa kali dilakukan dengan maksud menyesuaikan dengan perkembangan yang terjadi. Hal tersebut merupakan konsekuensi yang harus dihadapi organisasi pemerintah daerah sebagai bagian dari sistem birokrasi pemerintah yang dinamis.

Pada era konvergensi sekarang ini penataan organisasi pemerintah mempunyai sasaran untuk menciptakan struktur kelembagaan yang dinamis, efektif dan 
efisien, serta terciptanya sistem ketatalaksanaan yang terkait dengan penataan kewenangan dan hubungan kerja antara pemerintah pusat, provinsi dan kabupaten/kota untuk mendukung pelaksanaan otonomi daerah. Keluarnya Peraturan Pemerintah No. 41 Tahun 2007 tentang Organisasi Perangkat Daerah, menuntut pemerintah Kota Depok menata organisasi pemerintahan, termasuk perubahan satuan organisasi dibidang teknologi informasi dan komunikasi agar pengembangannya dikelola oleh satuan organisasi yang khusus, sehingga urusan arsip dan kehumasan dipisahkan dan dikelola oleh satuan organisasi tersendiri.

Pembentukan dan penempatan satuan kerja bidang TIK saat ini baru diarahkan pada tujuan dan optimalisasi tugas dan fungsi satuan kerja yang telah memberi dukungan serta menjalankan tugas antar satuan kerja, dengan kata lain domainnya di bidang TIK di laksanakan oleh Dinas Komunikasi dan Informasi, begitu pula OPD lainnya bekerja secara mandiri tanpa koordinasi dan sinergitas yang baik. Berdasarkan Peraturan Walikota Depok Nomor 26 Tahun 2008 tentang rincian, tugas, fungsi dan tata kerja Dinas Komunikasi dan Informatika Depok, ada 2 tugas pokok yang menjadi tanggung jawabnya, yaitu menyelenggarakan pelayanan urusan pemerintahan dan pelayanan umum dibidang komunikasi dan informatika.

Dalam urusan komunikasi dan informatika, ada dua tugas utama yang sudah dilakukan, yaitu :

1. Peningkatan akses informasi dan komunikasi bagi masyarakat dan jajaran birokrasi pemerintah. Era globalisasi berdampak kepada kebutuhan masyarakat akan informasi. Kebutuhan akan informasi dan selalu up to date dengan perkembangan dunia menjadi bagian dari kebutuhan primer masyarakat, yakni dengan membangun sebuah jaringan komunikasi dan informasi yang berbasis open source dalam bentuk electronic government (e-government) sejak tahun 2004. Ini diawali dengan dibangunnya website/situs resmi pemerintah dalam memberikan ruang gerak bagi masyarakat untuk ikut serta dalam proses pemerintahan dan pembangunan. Adapun faktor penghambat pelayanan umum di bidang TIK adalah anggaran TIK kurang memadai, sarana dan prasarana kurang memadai, dan kualitas sumber daya manusia masih kurang.

2. Informasi pemerintah dan pembangunan daerah, kebijakan pemerintah Kota Depok dan Kota Bogor penting untuk disosialisasikan kepada masyarakat secara formal maupun informal, untuk mendapatkan feed back sehingga kebijakan yang diambil dapat dirasakan masyarakat dan bisa sampai kepada tujuan yang ingin dicapai. Selama ini sosialisasi kebijakan dan program pembangunan dilaksanakan dengan sistem tradisional dalam bentuk leaflet, brosur, baliho, dan media cetak lainnya. Namun dengan memasyarakatnya internet dewasa ini, media digital/konvergensi semakin populer dan dianggap sebagai sarana sosialisasi yang paling efektif. Faktor penghambat dalam kegiatan ini, adalah fasilitas penunjang informasi dan komunikasi yang masih terbatas, serta perlunya peningkatan kerjasama dan dukungan dari berbagai OPD dalam penyampaian informasi.

Tugas dan fungsi satu SKPD dan saling berhubungan dan dapat dikerjakan secara bersama dalam memberikan pelayanan publik sudah tercermin dalam job description. Tetapi, sistem pengelompokan bidang dalam satuan kerja/unit belum cukup menjawab tantangan perkembangan TIK yang sangat pesat.

Untuk mencapai tujuan dalam organisasi Pemerintah Kota Depok dengan berbagai minimnya infrastruktur dan sumber daya manusia, peran pengelola informasi sebagai pelayan publik (bukan business oriented layaknya di perusahaan swasta) sangat diperlukan. Pemerintah dituntut untuk mewujudkan good governance, yaitu suatu pemerintahan yang memenuhi kriteria competence, transparency, dan accountability. Solusi yang sedang dan giat diupayakan guna mewujudkan interaktisi dari ketiga elemen tadi adalah dengan memanfaatkan TIK. 


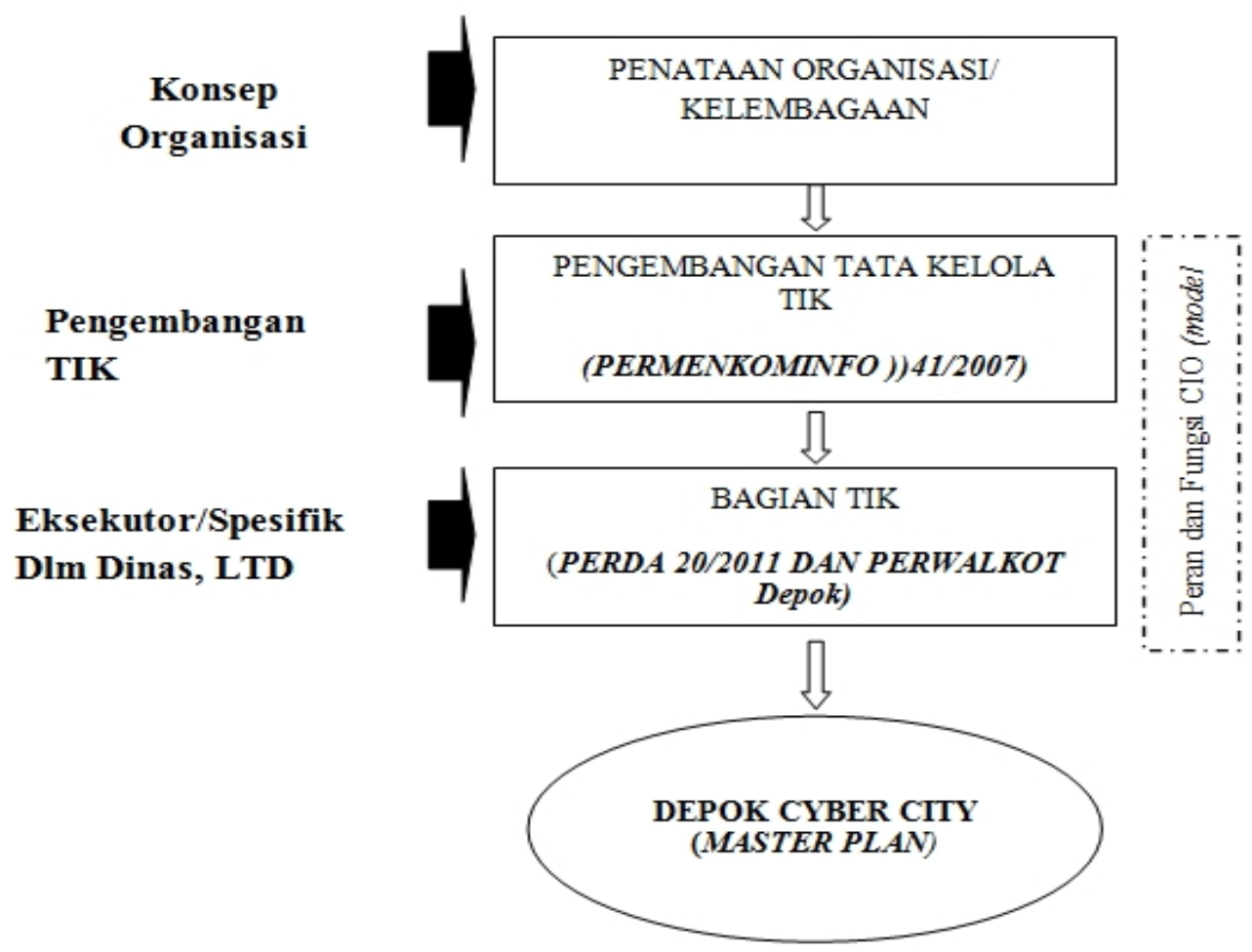

Sumber: Hasil Penelitian 2012

\section{Gambar 2}

\section{Konsep Kelembagaan TIK pada Pemkot Depok}

Namun, dalam perkembangannya TIK ini belum optimal dimanfaatkan masyarakat, seperti sebagian besar website pemerintah daerah selain data yang ditampilkan seringkali tidak up to date, juga kebanyakan tidak menampilkan informasi yang dicari masyarakat.

Kelembagaan pemerintah daerah yang secara khusus menangani bidang TIK sebagai leading sektor belum bekerja sesuai dengan visi dan misi pada Dinas Kominfo di kabupaten dan kota.

Lembaga yang ada di berbagai pemerintah daerah saat ini masih menggunakan nomenklatur yang berbeda, kelembagaan pemerintah daerah secara nasional telah diatur, sementara acuan kelembagaan yang khusus mengakomodir dan menangani bidang TIK dan seluruh tahapan pengembangan e-government dikeluarkan oleh Kementerian Komunikasi dan Informatika melalui Peraturan Menteri Kominfo Nomor 41 Tahun 2007 tentang
Panduan Umum Tata Kelola Teknologi Informasi dan Komunikasi Nasional.

Bedasarkan pada kenyataan tersebut, dapat digambarkan seperti pada gambar 2 tentang implementasi konsep penataan kelembagaan TIK pada pemerintah Kota Depok sesuai dengan visi misi serta policy yang ditetapkan.

\section{Urgensi Peran Jabatan CIO dalam Mengembangkan TIK}

Adanya kelembagaan pemerintah daerah yang telah diatur melalui Peraturan Pemerintah (PP), dinilai belum menempatkan peran komunikasi dan informatika yang lebih urgen, tetapi posisinya satu rumpun dengan tugas pokok dan fungsi perhubungan. Meskipun daerah diberi kesempatan berimprovisasi, namun hampir sebagian pemerintah daerah cenderung menjadikan fungsi serumpun sebagai satu dinas saja. Dengan pengembangan lembaga/SOTK yang 
stagnan seperti itu, perlu transformasi birokrasi yang lebih mumpuni bagi pengembangan TIK yang lebih baik lagi, terlebih jika dihadapkan pada pencapaian sasaran Millenium Development Goals (MDG's) pada tahun 2015. Kumorotomo, menjelaskan bagi sebagian besar pemerintah daerah, kendala yang menjadi penyebab kegagalan penerapan electronic government di Indonesia bisa berasal dari cara merekonstruksi lembaga birokrasi, cara ini dipengaruhi oleh adanya konflik antara kebijakan pemerintah pusat dengan pemerintah daerah, peraturan yang masih kurang mendukung, alokasi anggaran yang kurang memadai, pembakuan sistem yang tidak jelas, yang kesemuanya ditentukan oleh komitmen dari para pemimpin bagi terlaksananya e-government. Sudah banyak bukti bahwa keberhasilan pemanfaatan $e$ government di daerah memang sangat ditentukan oleh komitmen gubernur, walikota dan bupati di daerah yang bersangkutan. (http://kumoro.staff.ugm.ac.id)

Sementara itu, yang sangat mendasar dan memerlukan komitmen yang kuat bagi pengembangan TIK dalam kelembagaan pemerintah daerah adalah faktor visi pengembangan layanan secara elektronik, serta terbentur dengan faktor budaya birokrat dalam lembaga pemerintah sehingga mengakibatkan kurangnya kesadaran dan penghargaan terhadap pentingnya TIK. Pengembangan TIK di Pemerintah Kota Depok dan juga daerah lainnya di Jawa Barat masih rendah dalam integrasi di antara satuan kerja pemerintah daerah, karena terkendala masing-masing tidak mau berbagi data dan informasi. Beberapa SKPD ada yang telah memanfaatkan pengembangan e-government untuk keperluannya sendiri tanpa adanya sharing dengan yang lain dalam satu pemerintahan. Kondisi demikian, dinilai tidak mendukung karena koordinasi antar lembaga menjadi kurang berjalan dengan baik, perencanaan dan sinkronisasi perlu ada perubahan.

Oleh karena itu, untuk memperkuat struktur kelembagaan di pemerintah kabupaten dan kota dalam menjawab tantangan era globalisasi, perlu suatu jabatan khusus yang menangani TIK dalam OPD, sehingga pengembangan TIK diharapkan dapat meningkatkan aksesibilitas masyarakat terhadap informasi secara cepat dan handal, meningkatkan kualitas dan kuantitas informasi sebagai hak masyarakat, mengintegrasikan data dan aplikasi layanan informasi berbasis teknologi informasi, serta dapat melibatkan seluruh segmen masyarakat untuk memanfaatkan TIK sebagai diseminasi informasi. Hal ini sesuai dengan yang diarahkan pada forum APECTEL, yakni peran dari G-CIO dalam konteks kelembagaan pemerintah di lingkungan pemerintah daerah, diperlukan enterprise leadership sebagai kepemimpinan yang mencakup struktur perangkat daerah yang mutlak dilakukan dengan kondisi dan kebutuhan pemerintah kabupaten dan kota dan hanya dengan penyediaan informasi dan TIK harus ditempatkan dalam kerangka tugas lembaga pemerintah sebagai penyelenggara layanan publik.

Berdasarkan hal tersebut, pada level pemerintah daerah perlu dikembangkan suatu kerangka/struktur pemerintah yang bisa menjawab perkembangan TIK yakni dengan menempatkan Chief Information Officer (CIO) sebagai seorang yang memiliki tanggung jawab pada pengelolaan sistem informasi yang berbasiskan pada TIK dan dapat memformulasikan strategi untuk pencapaian tujuan pemerintahan. Meskipun istilah CIO masih asing bagi aparat pemerintah sebagai leading sector TIK, namun keberadaannya dalam struktur organisasi di tingkat pemerintah daerah diperlukan. Sedangkan pada level pusat yang berada di Kementerian Komunikasi dan Informatika (Kemenkominfo) adalah yang memegang otoritas/manajemen sistem informasi dari hulu sampai hilir.

Kultur CIO yang biasa ditemukan di dunia swasta dan berorientasi pada keuntungan (profit oriented), akan sangat beda dengan posisi CIO di pemerintahan (GCIO) yang berorientasi pelayanan publik. Dalam struktur pemerintahan yang diharapkan adalah pembentukan dan penempatan satuan kerja bidang TIK lebih diarahkan pada tujuan optimalisasi tugas dan 
fungsi satuan kerja yang memberi dukungan serta menjalankan tugas koordinasi. Sehingga satuan kerja yang dibentuk ditempatkan di lingkungan sekretariat dengan nomenklatur setingkat bagian. Fungsi analisis jabatan dalam kontek kelembagaan baru sangat urgen dilakukan, sehingga menghasilkan uraian jabatan dan persyaratan jabatan yang ada di bagian TIK lebih optimal.

Perlunya restrukturisasi organisasi ataupun penguatan fungsi kelembagaan yang menempatkan CIO dalam suatu jabatan yang urgen, diperkuat pendapat Soh Bong Yu yang menyatakan dalam upaya membangun TIK yang sukses maka faktor dominan yang perlu diperhatikan adalah adanya restrukturisasi organisasi, karena faktor ini akan memengaruhi sekitar 30 sampai 50 persen dari aktivitas organisasi. (http://unapcit.org)

Dalam hal keberadaan peran dan fungsi CIO, seluruh stakeholder di pemerintahan Kota Depok sepakat perlunya jabatan pada lembaga/OPD yang lebih strategis, koordinatif, dan teknis dengan tugas yang terfokus dan jelas, yaitu bidang Chief Information Officer dalam Kelembagaan Pemerintah Daerah.

Untuk menjawab dinamika perkembangan TIK, aspek kelembagaan menjadi prioritas kebijakan untuk mengevaluasi berbagai program yang terkait dengan teknologi informasi sebagaimana diamanatkan oleh Peraturan Menteri Kominfo No 41 Tahun 2007. Peraturan ini mengharapkan untuk menyelenggarakan pemerintahan yang baik (good governance) dan meningkatkan layanan publik yang efektif dan efisien diperlukan konsep tata kelola TIK yang jelas, seperti:

1. Untuk menjawab tantangan tersebut pemerintah daerah harus membentuk dimensi baru dalam organisasi, sistem manajemen.

2. Sistem dan proses kerja yang dilandaskan pada tatanan birokrasi yang kaku, tidak akan menjawab perubahan yang komplek dan dinamis, dan perlu ditanggapi secara cepat.

3. Perlu dikembangkan sistem manajemen modern dengan organisasi berjaringan sehingga dapat memangkas lini pengambilan keputusan serta memperluas rentang kendali

4. Dapat memanfaatkan kemajuan teknologi informasi untuk meningkatkan kemampuan mengolah, mengelola, menyalurkan dan mendistribusikan informasi dan pelayanan publik.

Dengan memperhatikan Permenkominfo tersebut, sebenarnya pemerintah daerah sejak tahun dikeluarkannya peraturan tersebutharus mengambil langkah secepatnya untuk mengembangkan sistem kelembagaan pemerintahan yang berbasis TIK dalam rangka meningkatkan kualitas layanan publik. Apalagi mulai tahun 2012 ini pemerintah pusat melalui Kementerian Pendayagunaan Aparatur Negara dan Reformasi Birokrasi (Kemenpan dan RB) akan melakukan reformasi birokrasi di seluruh lembaga kementerian dan nonkementerian sebagai solusi mendorong percepatan peningkatan daya saing daerah. Reformasi birokrasi merupakan perubahan terencana terhadap tatanan penyelenggaraan pemerintah terutama dengan aspek penataan kelembagaan atau organisasi, ketatalaksanaan dan penataan manajemen sumber daya manusia (SDM) aparatur pemerintahan.

Melalui reformasi birokrasi, diharapkan semua pihak dapat menilai dan menjadi tolok ukur perubahan kinerja pemerintahan maupun Pemerintah Daerah menuju Indonesia yang lebih baik, artinya harus dilakukan melalui suatu agenda aksi dengan prinsip-prinsip efisien, efektif, ekonomis serta produktif. Dalam konteks ini, sangatlah diapresiasi terhadap usaha pemerintah yang telah dan sedang melakukan beberapa perbaikan kebijakan dan regulasi, seperti revisi UU Pemerintah Daerah, UU Organisasi Kepegawaian, UU Organisasi Kemasyarakatan.

Reformasi birokrasi merupakan momen yang tepat bagi pemerintah Kota Depok dan daerah lainnya (kabupaten dan kota) untuk penataan OPD atau memberdayakan lembaga dengan peningkatan dan penguatan akuntabilitas kinerja sebagai syarat yang harus dipenuhi (sebaliknya bukan menambah kelembagaan yang sudah ada 
sehingga bentuknya semakin gemuk). Usaha yang perlu dilakukan adalah penataan organisasi/lembaga TIK yang mengakomodasi jabatan CIO (jabatan TIK) dalam suatu struktur kelembagaan pemerintahan, artinya keberadaan jabatan TIK yang sudah ada sebelumnya/baru mempunyai peran dan fungsi CIO guna memperkuat programprogram pemanfaatan TIK secara efektif lagi, baik dari sisi perencanaan, koordinasi maupun pelaksanaan (eksekusi). Dengan demikian, jabatan CIO dapat berfungsi sebagai agent of change dalam pengembangan TIK.

Keberadaan CIO dalam kelembagaan perlu ditempatkan pada level strategis setingkat di bawah sekretaris daerah yang dapat mengakomodasi seluruh kepentingan SKPD setingkat dinas, kantor, badan, dan lembaga teknis daerah. Semua OPD pada pemerintahan daerah sangat berkepentingan dengan pemanfaatan TIK, sehingga TIK ini bukan domainnya Diskominfo saja, tetapi seluruh SKPD pada pemerintah daerah tidak lepas dari pemanfaatan TIK. Tugas dari Diskominfo hanyalah sebagai pelaksana teknis untuk merumuskan dan melaksanakan kebijakan di bidang komunikasi dan informatika dan pengolahan data elektronik yang meliputi pemberdayaan sistem informasi, komunikasi, diseminasi informasi, dan pengembangan aplikasi telematika.

Dengan jabatan eselon tertinggi terletak pada level di bawah sekretaris daerah (Sekda), berarti secara struktural SKPD di bawahnya menjadi tanggung jawabnya, otomatis komunikasi dan koordinasi dengan Kepala daerah bupati atau walikota akan lebih sinergis. Di samping itu, keberadaan CIO sebagai pimpinan tertinggi di bidang pengembangan TIK/e-government di pemerintah daerah akan mampu mengoordinasikan, merencanakan, merealisasikan, mengoperasionalisasikan serta mengevaluasi pada setiap satuan kerja dan pengguna TIK lainnya. Haryadi Supangkat menyatakan, keberadaan jabatan CIO dalam struktur tersebut, akan lebih optimal dalam memberikan pelayanan publik, yakni :

1. TIK sebagai support, yang mendukung jalannya organisasi dan otomatisasi dari back office sebuah organisasi dan menjadikan pelengkap dari suatu pemerintahan.

2. TIK sebagai enabler, penggerak dan kekuatan utama dalam suatu organisasi.

3. TIK sebagai driver, sebagai sarana untuk mengembangkan layanan, dimana dengan kapabilitas TI yang dimiliki sebuah organisasi/perusahaan dapat melakukan ekspansi layanan.

4. TIK sebagai transformer, berfungsi untuk menentukan arah aktivitas organisasi. (dalam Supangkat, 2008)

5. Dalam PP No. 41 Tahun 2007, Sekda berada pada eselon IIa yang membawahi secara langsung bagian-bagian yang bersinggungan dengan TIK sebagai satu kesatuan hubungan fungsional dengan eselon atau jabatan di bawahnya, baik pada level badan perencanaan pembangunan daerah (Bappeda), maupun pada level lembaga teknis yang ditempatkan pada setiap SKPD terutama pada Dinas Komunikasi dan Informasi. Dengan demikian, eselonisasi yang terdapat pada pemerintahan daerah dengan jabatan eselon tertinggi terletak pada seorang Sekda. meskipun eselon kepala dinas/badan satu eselon dengan asisten Sekda yang menangani TIK (di bawah Sekda eselon IIb), tetap secara etika birokrasi menempatkannya dalam koordinasi Sekda.

Level CIO ditempatkan pada jabatan Asisten Sekda Bidang Komunikasi dan Informatika (eselon IIb) secara struktural akan lebih tepat sebagai pelaksana (eksekutor) dilakukan oleh bagian humas dan bagian komunikasi dan informatika. Meskipun posisi CIO lebih fokus atau berperan pada bagian teknologi informatika dan komunikasi (TIK), bagian humas masih tetap diperlukan sebagai fungsi kesekretariatan daerah yang mengatur desiminasi informasi dan protokoler pemerintahan. Atau dengan kata lain, pembagian lahan kerja antara kehumasan dan TIK akan lebih banyak oleh komitmen konsesi antara siapa yang membangun teknologi informatika dan komunikasi, sehingga adanya suatu sistem yang 


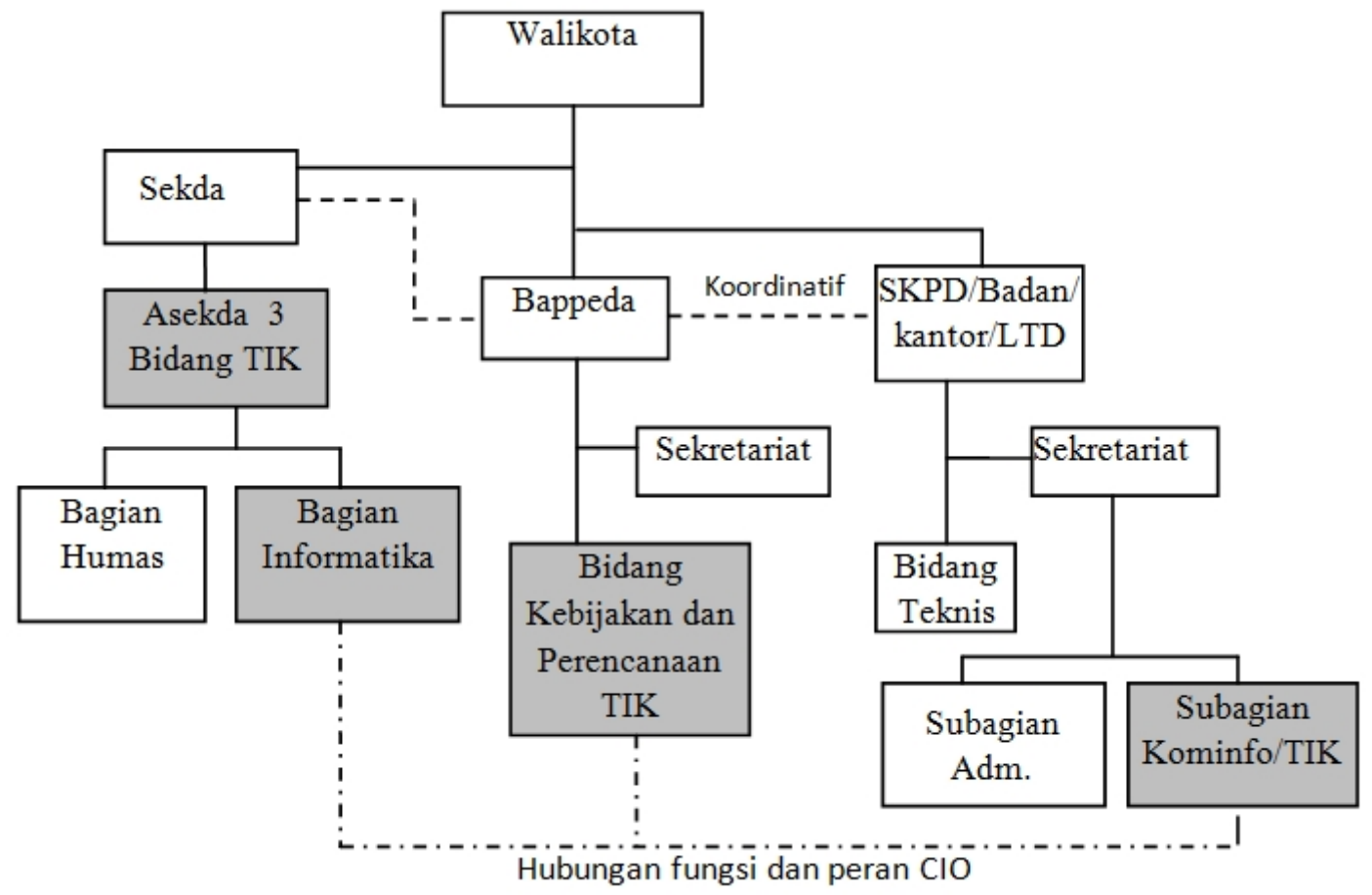

Sumber: Hasil Penelitian 2012

\section{Gambar 3 \\ Model Ideal Posisi Chief Information Officer dalam OPD}

memungkinkan harapan pemerintah daerah dapat diterjemahkan, begitu pula siapa yang akan membangun komitmen kehumasan disesuaikan dengan pola koordinasinya. Seorang asisten Sekda CIO harus bisa memanage dua bagian yang dibawahnya siapa yang membangun teknologi informasi dan konten, dan siapa yang membangun sistem. Dengan demikian posisi CIO dalam OPD dapat digambarkan dalam sebuah model seperti pada gambar 3 .

Dalam Forum Sekretaris Daerah Seluruh Indonesia (Forsesdasi), disebutkan bahwa Sekretaris daerah sangat strategis untuk memberikan gambaran mengenai desain besar dan rencana aksi untuk daerah masing-masing. Di samping itu Sekda memiliki peranan dan kontribusi besar dalam upaya melakukan reformasi birokrasi. Sedangkan alternatif lain yang menempatkan level CIO di bawah Sekda, akan lebih tepat ditempatkan pada Badan Perancanaan Pembangunan Daerah (Bappeda) eselon IIb yang ditempatkan pada jabatan Kepala bidang $\mathrm{CIO} /$ eselon IIIa. Bappeda diharapkan sebagai enabler pengembangan TIK, dapat berfungsi: sebagai pihak penyelaras dan jembatan dalam sistem dan proses birokrasiyang saat ini pemanfaatan TIK kurang optimal, sebagai kapabilitas koordinasi fungsional dalam menyinergikan rencana dan implementasi TIK, serta sebagai perancang anggaran TIK yang dibutuhkan bagi operasional pengembangan. Dengan fungsi tersebut, maka posisi/jabatan CIO di Bappeda selain sebagai perancang juga sebagai koordinator antara lembaga teknis di bawahnya dengan jabatan CIO di Sekda, seiring dengan misinya, yakni: memantapkan sistem pengelolaan perencanaan pembangunan daerah yang terintegrasi dan transparan, dan meningkatkan sinergitas penyelenggaraan perencanaan pembangunan internal daerah.

Posisi jabatan CIO di Bappeda kabupaten dan kota sebagai perencana kebijakan TIK akan lebih optimal ketika lembaga teknis TIK mengajukan sebuah anggaran (perangkat keras, jaringan, perangkat lunak dan data) dalam bentuk Raperda untuk selanjutnya bisa disetujui oleh 
Tabel 2

Matrik Tentang Peran Dan Tanggung Jawab Masing-Masing OPD

\begin{tabular}{|c|c|c|}
\hline $\begin{array}{c}\text { OPD } \\
\text { (Koordinator) }\end{array}$ & PERAN & $\begin{array}{c}\text { PELAKSANA CIO } \\
\text { (EKSEKUTOR) }\end{array}$ \\
\hline Sekda & $\begin{array}{l}\text { - Mengakomodasi kepentingan setiap SKPD dalam } \\
\text { pengembangan TIK } \\
\text { mengoordinasikan dan mengkomunikasikan dengan } \\
\text { kepala daerah (walikota/bupati) tentang strategi } \\
\text { pengembangan TIK secara sinkron. } \\
\text { - } \text { Mengoordinasikan pelaksanaan implementasi TIK } \\
\text { membangun TIK di daerah dan menjamin pelaksanaan } \\
\text { secara efektif, serta membina aparatur daerah yang } \\
\text { terkait dengan implementasi TIK. }\end{array}$ & $\begin{array}{c}\text { Assekda Komunikasi dan } \\
\text { Informatika . Bidang } \\
\text { Humas dan Bidang } \\
\text { Informatika }\end{array}$ \\
\hline Bappeda & $\begin{array}{l}\text { - Merencanakan, mengomunikasikan dan mengevaluasi } \\
\text { strategi pengembangan TIK dengan lingkup struktural } \\
\text { menjalankan peran manajemen sistem informasi mulai } \\
\text { dari hulu sampai hilir } \\
\text { memberikan gambaran sesuai dengan masterplan untuk } \\
\text { merencanakan kebijakan pengembangan TIK untuk } \\
\text { masing-masing OPD. } \\
\text { Mengoordinasikan perencanaan pengembangan sistem } \\
\text { dan teknologi informasi secara selaras dan sinergis }\end{array}$ & $\begin{array}{l}\text { Bidang Kebijakan dan } \\
\text { Perencanaan Teknologi } \\
\text { Informasi dan } \\
\text { Komunikasi }\end{array}$ \\
\hline $\begin{array}{l}\text { SKPD (setingkat dinas, } \\
\text { kantor, dan LTD) }\end{array}$ & $\begin{array}{l}\text { - } \quad \text { Memberikan pelayanan publik kepada secara langsung } \\
\text { - } \\
\text { pengusulkan, mengadakan dan menjalankan program } \\
\text { yang dibuat. } \\
\text { - } \quad \text { Berkoordinasi dengan setiap unit SKPD } \\
\text { - } \text { membuat draf pengusulan anggaran yang dibutuhkan. } \\
\text { - } \text { Merumauskan kebijakan teknis untuk pemanfaatan TIK } \\
\text { sesuai dengan lingku tugas SKPD }\end{array}$ & Subbagian TIK \\
\hline
\end{tabular}

pihak legislatif. Hal ini akan terwujud bila seluruh organisasi perangkat daerah (OPD) secara sinergi bisa mendukungnya. Sehingga fungsi dan perannya sebagai lembaga teknis daerah yang bertanggung jawab terhadap perencanaan pembangunan termasuk pembangunan TIK dapat berjalan, sebagaimana diamanatkan pada pasal 14 (1) Undang-Undang Nomor 32 Tahun 2007, Tentang Pemerintahan Daerah.

Tidak jauh berbeda dengan tugas pokok dan fungsi yang diemban jabatan CIO pada level Asisten Sekda, secara umum Badan ini dapat menjalankan peran manajemen sistem informasi yang mengelola data dan informasi dari hulu sampai hilir dan tetap mewajibkan adanya struktur yang berfungsi mengelola komunikasi dan informasi pada setiap SKPD. Keberadaannya akan memungkinkan seorang CIO dapat melakukan komunikasi efektif dengan bupati atau walikota serta sekda secara langsung. Berbeda dengan jabatan CIO yang teknis, posisi jabatan CIO di Badan mutlak harus diisi oleh seorang yang berlatar belakang pendidikan teknologi informatika dan menguasai sangat teknis seperti halnya pada jabatan CIO di swasta. Lebih dari itu, dia mempunyai leadership terhadap bawahannya dan visi misi yang jelas, serta seseorang dengan kualifikasi yang mampu memadukan keinginan pimpinan dan tuntutan core bisnis pemerintah melalui teknologi informasi dan komunikasi. Dan sudah bukan waktunya lagi 
memercayakan job pengelola TIK kepada seseorang pejabat yang didasarkan pada jabatan karier belaka.

Selanjutnya untuk posisi terakhir jabatan CIO adalah pada dinas (SKPD) atau lembaga teknis daerah eselon IIb, biasanya untuk lembaga teknis yang langsung menangani berada pada bidang dan subbidang TIK atau pada eselon IIIa yang secara langsung bersinggungan dengan pelayanan masyarakat. Jabatan tersebut akan selaras dengan Peraturan Pemerintah Nomor 41 Tahun 2007, di mana tugas dinas adalah melaksanakan urusan pemerintahan daerah berdasarkan asas otonomi dan tugas pembantuan. Tugas bidang atau subbidang TIK adalah mengusulkan, mengadakan, dan menjalankan program-program atas kebijakan perencanaan TIK, sehingga koordinasi antara dua unit ini pada saat pengusulan program (anggaran) akan baik. Selama ini, setiap pengusulan anggaran oleh setiap dinas (Dinas Komunikasi dan Informatika) ke dewan selalu hasilnya tidak sesuai dengan harapan.

Berdasarkan pada uraian tentang jabatan CIO dalam kelembagaan pemerintah daerah tersebut, dapat digambarkan dalam sebuah matrik tentang peran dan tanggungjawab dari masing-masing OPD seperti pada Tabel 2.

\section{Komparasi Penelitan Model Jabatan CIO pada OPD}

Penelitian terdahulu yang digunakan sebagai masukan dalam perbandingan model (OPD) yang digunakan, terdapat perbedaan struktural dalam mengakomodasi kebutuhan jabatan CIO, di samping terdapat persamaan fungsional dalam menempatkan posisi jabatan CIO di pemerintahan. Dari kedua penelitian yang dilakukan, ternyata peran Sekda diperlukan untuk mengakomodasi pengembangan TIK yang lebih optimal, karena posisi CIO akan lebih sinergi lagi dengan struktur kelembagaan di bawahnya, juga informasi dan komunikasi dengan kepala daerah akan lebih koordinatif. Sedangkan perbedaan yang signifikan terhadap kelembagaan tersebut, terletak pada karakter nama posisi CIO yang berlainan mulai dari eselon 2 sampai 4. Hasil komparasi dengan dua penelitian yang telah dilakukan sebelumnya terlihat pada tabel 3 .

Matrik tersebut, tergambar dominasi jabatan tertinggi CIO yang berada pada posisi Sekretaris Daerah (Sekda) sebagai orang ketiga pada suatu pemerintahan daerah (setelah Bupati dan Wakil Bupati). Hal ini menunjukkan bahwa semua komunikasi birokrasi kepada Bupati atau Walikota harus sepengetahuan Sekda, bahkan meskipun eselon Kepala Dinas/Badan satu klik di bawah Sekda, tetap kultur birokrasi menempatkannya dalam koordinasi Sekda. Oleh karena itu, posisi CIO di level Sekda sangat strategis ditempatkan.

Ketiga kajian yang menempatkan jabatan CIO di Sekda, hanya kajian dari Dwi Anggono (Kominfo) yang secara langsung jabatan tersebut di pegang oleh Sekda sekaligus mempunyai posisi koordinator dengan eselon di bawahnya, yakni dengan dibentuk suatu badan tersendiri yang menangani TIK (bukan Bappeda), yaitu Badan Komunikasi dan Informatika dengan dibagi dua bidang yang menangani yaitu: Bidang Komunikasi (Kehumasan) dan Bidang Informatika.(http://ibenkda.blogspot.com)

Sedangkan hasil kajian dari MTI UGM, CIO ditempatkan pada level Asisten Sekda (eselon 2b) yaitu bagian Asekda Administrasi dan Informasi sebagai operasional teknis. Hal ini beralasan karena posisi Sekda mempunyai tugas dan tanggung jawab yang banyak, dan selayaknya tugas operasional dari CIO dipercayakan kepada Asisten Asekda.

Dari kajian tersebut, hanya MTI UGM dan hasil kajian ini yang menempatkan CIO setelah Sekda berada pada kelembagaan Bappeda sebagai perencana strategis dan mengakomodasi kepentingan dari SKPD di bawahnya. Sedangkan kajian Dwi Anggono menempatkan CIO pada level badan tersendiri yaitu Badan Komunikasi dan Informatika (bukan Bappeda), di mana bidang komunikasi dan kehumasan bersifat administratif dan bagian informatika sebagai operasional teknis.

Selanjutnya untuk peran pelaksana (eksekutor) yang bersifat sektoral dan 
Tabel 3

Komparasi Penelitan Model Jabatan CIO Pada OPD

\begin{tabular}{|c|c|c|c|c|}
\hline Kajian & & Posisi CIO & & $\begin{array}{l}\text { Hubungan Struktural } \\
\text { Tugas dan Peran CIO }\end{array}$ \\
\hline $\begin{array}{l}\text { MTI. Universitas } \\
\text { Gajah Mada }\end{array}$ & $\begin{array}{c}\text { Sekda } \\
\text { (Asekda } \\
\text { Adm. Dan } \\
\text { Informasi) }\end{array}$ & $\begin{array}{c}\text { Bappeda } \\
\text { (Bidang Perencanaan } \\
\text { TIK) }\end{array}$ & $\begin{array}{c}\text { SKPD } \\
\text { (Sub Bidang TIK) }\end{array}$ & $\begin{array}{l}\text { Antar OPD bersifat } \\
\text { koordinatif. }\end{array}$ \\
\hline $\begin{array}{l}\text { Dwi Anggono } \\
\text { (Kominfo) }\end{array}$ & Sekda & $\begin{array}{l}\text { Di bentuk : Badan } \\
\text { Komunikasi dan } \\
\text { informatika) : } \\
\text { 1. Bidang komunikasi } \\
\text { (kehumasan), sebagai } \\
\text { operasional } \\
\text { administrasi. } \\
\text { 2. bdg informatika, } \\
\text { sebagai operasional } \\
\text { teknis. }\end{array}$ & $\begin{array}{l}\text { Badan/kantor/ } \\
\text { Dinas/Kecamatan/ } \\
\text { Sekolah (SKPD), } \\
\text { ditempatkan pada } \\
\text { sub bag. kominfo }\end{array}$ & $\begin{array}{l}\text { Sekda dengan Badan } \\
\text { Kominfo bersifat } \\
\text { koordinatif. } \\
\text { Badan Kominfo dengan } \\
\text { SKPD bersifat } \\
\text { fungsional. }\end{array}$ \\
\hline $\begin{array}{l}\text { Hasil Kajian } \\
\text { (Kualitatif) }\end{array}$ & $\begin{array}{c}\text { Sekda, } \\
\text { Assekda } \\
\text { InformatikaB } \\
\text { idang Humas } \\
\text { dan Bidang } \\
\text { Informatika }\end{array}$ & $\begin{array}{c}\text { Bappeda, } \\
\text { Bidang Kebijakan dan } \\
\text { Perencanaan TIK. }\end{array}$ & $\begin{array}{l}\text { Dinas/Kantor/LTD/ } \\
\text { Badan (SKPD) } \\
\text { Bidang Kominfo } \\
\text { (Sub Bidang TIK) }\end{array}$ & $\begin{array}{l}\text { Sekda,Bappeda, dan } \\
\text { OPD bersifat } \\
\text { koordinatif. Sdkn } \\
\text { bidang-bidang tik } \\
\text { adalah fungsional. }\end{array}$ \\
\hline
\end{tabular}

Sumber: Komparasi Hasil Penelitian (Diolah)

spesifik, fungsi CIO dilaksanakan oleh seluruh SKPD, bahkan kajian dari Dwi Anggono menempatkan fungsi CIO lebih luas lagi, selain pada Badan, Kantor, dan Dinas juga berada di sekolah-sekolah dan kantorkantor kecamatan. Dimana dalam posisi terakhir sebagai pelaksana harus dapat menerjemahkan kebijakan-kebijakan perencanaan TIK menjadi program-program implementasi TIK. Pada posisi ini pula, posisi CIO secara langsung bersinggungan dengan pelayanan masyarakat melalui pengembangan e-goverment yang diimplementasikan dengan keberadaan website (front-office) maupun keberadaan TIK sebagai pendukung dari aktivitas TIK (back-office).

\section{Kompetensi CIO di Era Reformasi Birokrasi}

Reformasi birokrasi pada pemerintah daerah merupakan kebutuhan dalam mewujudkan pemerintah yang baik (good governance), yang diarahkan terciptanya organisasi yang efisien, efektif sesuai dengan kebutuhan dan kemampuan daerah serta tingkat koordinasi, sinkronisasi dan komunikasi kelembagaan lebih optimal. Dalam penyelenggaraan pemerintah harus diformulasikan berdasarkan prinsip-prinsip manajemen yang baik antara unsur: pimpinan, staf, pengawas, perencana, pelaksana, pendukung dan pelayanan.

Penempatan jabatan CIO dalam besaran susunan organisasi dinilai sesuai dengan semangat reformasi birokrasi, termasuk dalam implementasi UndangUndang No. 14/2008 tentang Keterbukaan Informasi Publik (KIP), diperlukan perannya selaku eksekutif yang bertanggung jawab dalam perencanaan, penyelarasan, penyiapan, implementasi dan evaluasi di dalam penyelenggaraan teknologi informasi dan komunikasi pada instansi pemerintah. Selain dari segi teknis, pemerintah dapat meningkatkan pelayanan informasi kepada publik baik oleh jabatan CIO maupun Pejabat Pengelola Informasi Daerah (PPID) yang 
mempunyai domain tugas dan peran yang berbeda.

Posisi jabatan CIO yang ditempatkan pada Sekertaris Daerah (eselon 2) berdasarkan ketentuan reformasi birokrasi keberadaannya dipertahankan, sedangkan untuk jabatan di tingkat eselon 3 dan eselon 4 mulai tahun 2012 ini akan dihilangkan secara bertahap dan akan diganti dengan jabatan fungsional atau sistem remunerasi yang berbasiskan kinerja, seperti halnya sudah diberlakukan di Kementerian Keuangan dan kementerian lainnya. Dengan sistem tersebut akan dituntut menghasilkan kinerja yang sesuai dengan tuntutan pekerjaan dalam organisasi, dan memiliki integritas yang sesuai dengan harapan masyarakat, karena kalau tidak, akan berdampak pada jabatan dan sistem remunerasi yang diberikan. Dalam konteks jabatan CIO di tingkat eselon 3 dan 4, untuk menentukan penyusunan peringkat jabatan (job grading) yang berbasis kinerja yang merupakan dasar penetapan remunerasi, diperlukan analisis dan evaluasi untuk memperoleh data jabatan yang tepat.

Keberadaan posisi jabatan CIO tidak akan menambah struktur OPD menjadi gemuk, karena keberadaannya akan lebih memberdayakan jabatan TIK yang sudah ada, sesuai dengan peran dan fungsi jabatan CIO. Pemerintah Kota Depok dan daerah lainnya harus tanggap melakukan penataan kelembagaan dan meningkatkan SDM yang profesional di bidang TIK. Untuk itu perlu dikembangkan manajemen SDM berbasis kompetensi yang dipersyaratkan dalam kompetensi jabatan, yaitu suatu sistem pengukuran yang berbasis transparansi dan akuntabilitas dengan sistem yang fair dan objektif sehingga bisa diterima oleh kelembagaan pemerintah sebagai pelayan publik.

Melalui standar kompetensi sebagai awal assessment terhadap jabatan CIO, perlu follow up berupa pembinaan berbasiskan kinerja melalui program-program pendidikan dan pelatihan, bimbingan teknis, seminar dan lain-lain. Adanya paradigma untuk memprioritaskan para pegawai dari Dinas Kominfo untuk dibina melalui diklat, melanjutkan pendidikan ke jenjang S2 (program CIO), dan lain-lain yang selama ini dilakukan hendaknya diubah, yakni dengan memberi seluas-luasnya kepada para pegawai dari SKPD lainnya, sehingga adanya pemerataan kesempatan untuk meningkatkan SDM di bidang teknologi informasi dan komunikasi (TIK). Begitu pula dalam sistem perekrutan pegawai baru perlu dibuat framework yang baku sesuai dengan perkembangan TIK, yakni dengan memprioritaskan pegawai yang berlatar belakang teknologi informatika. Wheelen dan Hunger menyatakan untuk memengaruhi dan implementasi strategi dalam organisasi, sejalan dengan perubahan keberadaan fungsi TIK dari operasional menjadi strategi, sumber daya manusia perlu diberikan arah strategis sebagai strategic planning (Hunger, 2004).

Berdasarkan pada peran tersebut, maka jabatan CIO dalam posisi struktural juga pada jabatan fungsional harus mempunyai tiga kelompok kompetensi, yaitu:

1. Kompetensi teknis, yaitu kompetensi penguasaan teknologi informasi yang berperan sebagai fasilitator dalam pemanfaatan TIK yang digunakan dalam pengembangan e-government, termasuk dalam penguasaan hardware dan software dan melakukan penyesuaian terhadap teknologi baru. Dwiyanto menyatakan, bahwa teknologi informasi yang harus dikuasai dalam mewujudkan e-government, meliputi: jaringan informasi, arsitektur teknologi informasi, basis data multimedia, pemrograman internet/web, keamanan teknologi informasi, tata kelola teknologi informasi, bussiness continuity planning, manajemen layanan dan teknologi informasi (Dwiyanto, 2005)

2. Kompetensi manajemen teknologi informasi yang mencakup pengembangan pengetahuan dan keterampilan dalam manajemen teknologi informasi. Eksistensi dalam tata kelola pemerintahan bersinggungan dengan perencanaan strategis teknologi informasi menuju pengembangan TIK yang lebih baik. 

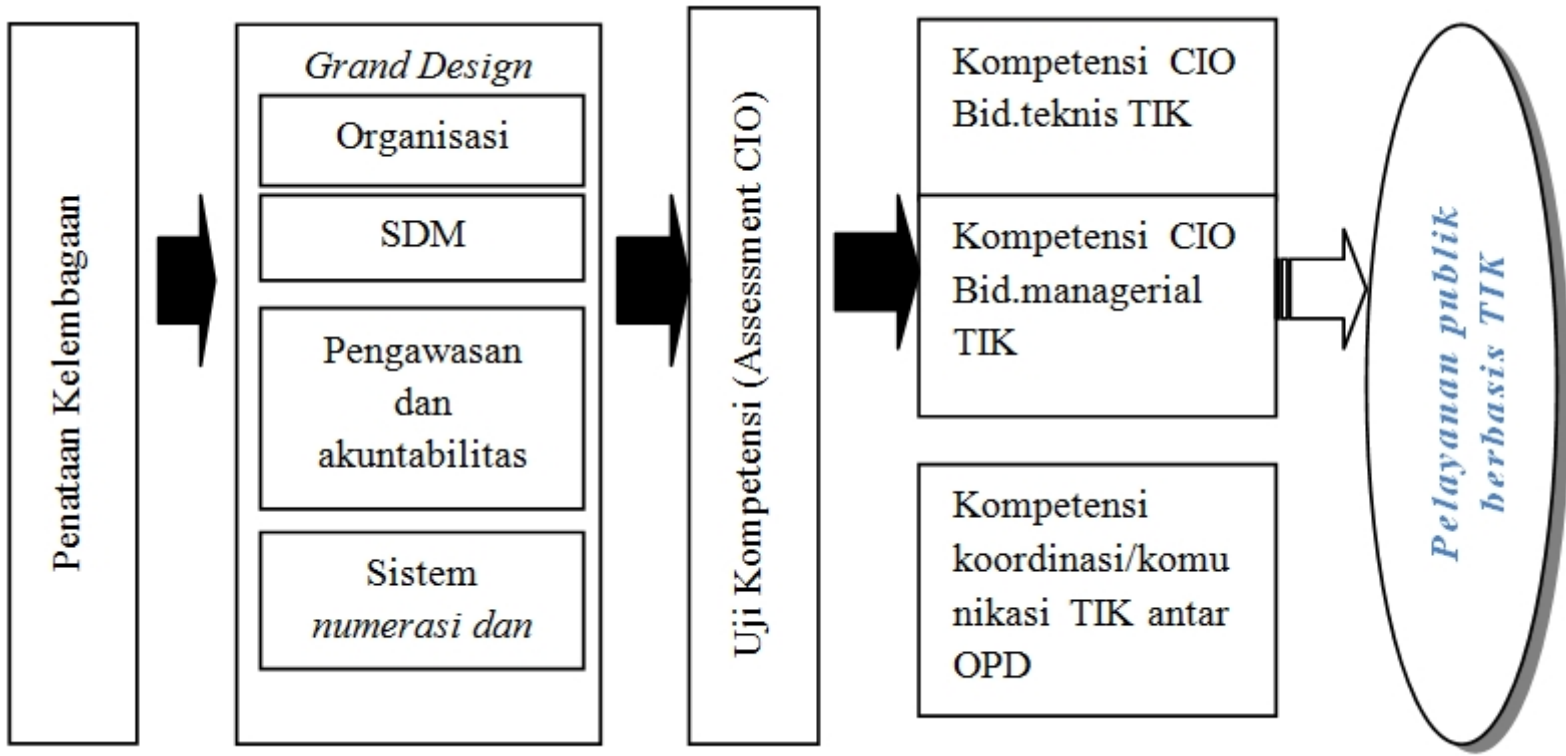

Sumber: Hasil Penelitian 2012

\section{Gambar 4}

\section{Kompetensi CIO dalam Posisi Kelembagaan/Struktural.}

3. Kompetensi koordinasi dalam pengambilan keputusan terutama dalam meningkatkan koordinasi antar-OPD, menciptakan keberadaan jalur-jalur komunikasi digital yang lebih efektif dan dapat meningkatkan pelayanan kepada masyarakat dengan menciptakan sistemsistem pelayanan elektronik yang lebih paraktis, cepat, lebih transparan dan lebih akuntabel.

Dengan tiga kompetensi tersebut, konsep tata kelola pengembangan TIK pada pemerintah daerah sebagai sistem informasi yang terpadu akan mendukung kegiatan pemerintahan, termasuk dalam hal melakukan proses-proses pelayanan kepada masyarakat. Aspek pelayanan masyarakat dimaksudkan sebagai front-office dari fungsi TIK dalam konsep e-goverment, sedangkan aspek manajemen pemerintahan, termasuk aspek komunikasi koordinasi adalah fungsi backoffice. Pengelolaan data informasi merupakan aspek antara yang bersifat back-office pada saat fungsinya adalah pengelolaan untuk kepentingan internal kantor pemerintah, dan dapat pula bersifat front-office pada saat penyajian data/informasi yang dimanfaatkan sebagai salah satu bentuk pelayanan kepada pihak luar (pelayanan publik). Dari paparan tersebut, dapat disimpulkan bahwa kompetensi jabatan CIO dapat digambarkan seperti pada Gambar 4.

\section{Tata Kelola dalam Kelembagaan TIK}

Program pengembangan TIK di pemerintah Kota Depok dan daerah lainnya yang mencakup infrastruktur teknologi, informasi, aplikasi dan sumberdaya manusia adalah menjadi faktor utama yang perlu dibenahi oleh seorang Chief Information Officer (CIO), karena faktor ini diperlukan untuk membangun visi, menentukan arah pembangunan, sasaran dalam memimpin perubahan.

Seorang pejabat CIO pemerintah mempunyai peran dan tanggung jawab terhadap proses perencanaan dan pengembangan sistem dan teknologi informasi, di mana tata kelola TIK di OPD Pemda selama ini berjalan sendiri-sendiri dan tidak terpola secara integral. Keberadaannya diharapkan dapat mengoordinasikan secara integratif dan menjamin lancarnya implementasi TIK, sehingga dapat memberikan kontribusi signifikan bagi aktivitas kantor sebagai pelayanan publik. Secara umum, Darono menyatakan, manfaat 
dari penerapan tata kelola TIK dengan didukung kompetensi seorang CIO, yakni: (1) membangun kepercayaan, keputusan, serta akuntabilitas yang transparan. (2) tata kelola TIK memadukan strategi TIK, bilamana memiliki sistem yang jelas dan robust, sehingga akan lebih efektif dalam memadukan strategi dengan konteks bisnis (Darono,2011).

Dalam membangun TIK di pemerintah daerah, faktor SDM adalah menjadi tanggung jawab seorang CIO membentuk para pegawai pemerintah yang profesional. Seorang CIO yang berlatar belakang pendidikan teknis/komputer, mengetahui benar terhadap tuntutan dan kebutuhan kantor pemerintah serta kompleksitas yang dihadapi para pegawai terhadap pemanfaatan TIK. Mulai dari merencanakan dan mengembangkan sistem informasi yang dibutuhkan oleh pemerintah daerah.

Harso Supangkat menyatakan, bahwa: misi terakhir dari seorang CIO dalam organisasi dan pemerintahan yaitu merencanakan dan mengembangkan arsitektur sistem informasi, yang terdiri dari komponen-komponen software, hardware, brainware, proses dan prosedur, infrastruktur, standar dan lain-lain. Serta harus dapat mengutilisasikan sistem informasi yang dimiliki organisasi secara optimum, sejalan dengan rencana pengembangannya di masa mendatang (Supangkat, 2008)

Jabatan CIO pada pemerintah daerah harus mempunyai sense of priority terhadap alokasi sumberdaya teknologi informasi pada setiap bagian pemerintahan, harus bisa membuat struktur prioritas yang menjadi kebutuhan, sehingga mempunyai kerangka kerja secara menyeluruh (integratif) sesuai dengan masterplan (renstra) yang telah disusun.

Arah kebijakan implementasi TIK yang memprioritaskan layanan publik berbasis TIK, adalah wujud dari visi dan misi Kota Depok sebagai cybercity berbasis komunitas yang harus dibangun dengan penjabaran sampai pada target yang akan dicapai oleh setiap bidang pemerintah daerah. Dengan keterbatasan sumber daya, terutama anggaran dan sumber daya manusia (SDM), pemerintah daerah memerlukan tata kelola TIK yang handal dalam memberikan pelayanan publik. Pengelolaannya perlu mempunyai kerangka (framework) dan perencanaan yang jelas terhadap kebutuhan TIK sebagai sarana pendukung, dan berkoordinasi dengan bagian lainnya yang mempunyai pelayanan secara langsung kepada masyarakat. Koordinasi dan sinergitas dari berbagai SKPD dalam pelayanan publik mempunyai prioritas-prioritas pengembangan TIK secara jelas dan berkesinambungan yang akhirnya membentuk TIK Pemda yang terintegrasi, sehingga pengelolaan data-data yang berada di bawah kendali Pemda dapat dikelola dengan baik, seperti masalah kependudukan, perizinan, pendapatan daerah, swakolola, keuangan daerah dan sebagainya.

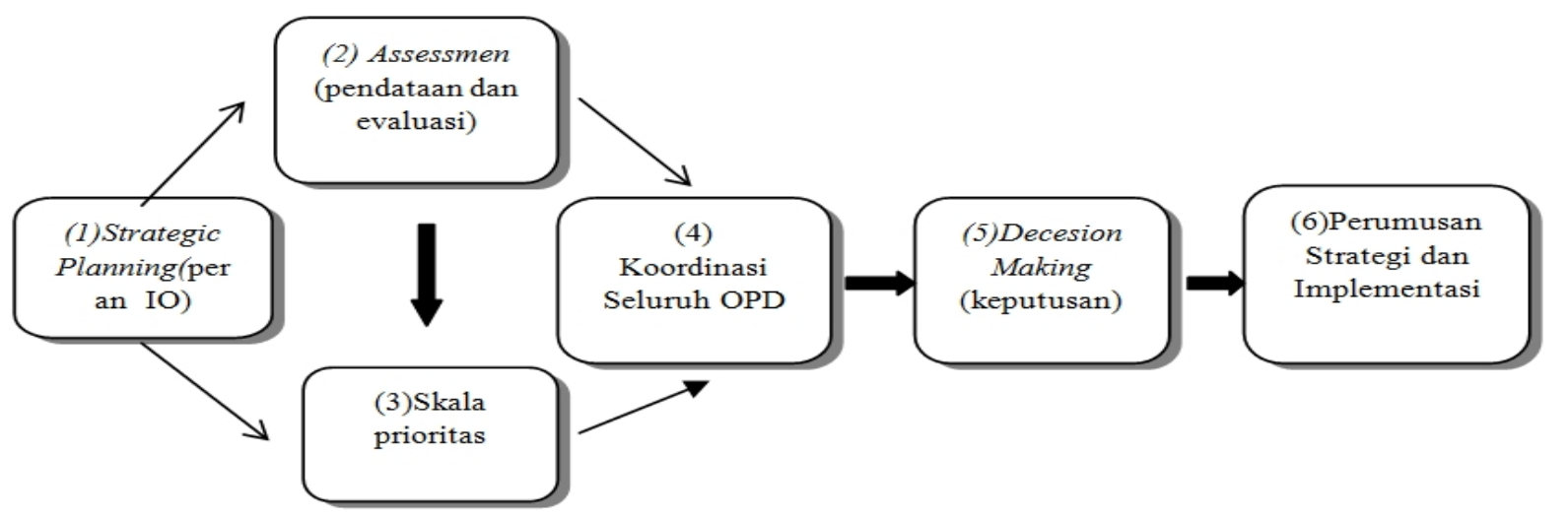

Sumber: Hasil Penelitian 2012

Gambar 5

Peran CIO Dalam Tata Kelola TIK 
Tata kelola yang dibangun secara konseptual, akan menjamin efektivitas strategi dan efisiensi operasional pada pemerintahan, yang akhirnya terbentuk IT governance yang terpola dengan baik, yakni cara bagaimana perencanaan, keputusan, dan pengawasan/evaluasi dapat diimplementasikan oleh seorang pimpinan (CIO). Sehingga penggunaan sarana dan prasarana teknologi informasi yang diinvestasikan dengan dana besar oleh pemda dapat didayagunakan secara optimal. Berdasar pada hal tersebut, peran $\mathrm{CIO}$ dalam tata kelola (framework) TIK pada pemerintah daerah, digambarkan seperti pada Gambar 5.

\section{PENUTUP}

\section{Simpulan}

Penataan kelembagaan dalam OPD Pemerintah Kota Depok, menempatkan jabatan CIO pada level strategis setingkat di bawah Sekretaris Daerah yang dapat mengakomodasi seluruh kepentingan satuan kerja pemerintah daerah, berkoordinasi dengan posisi CIO pada Badan Perencanaan Daerah (eselon II/b) serta pada level pelaksana atau eksekutor.

Peran dan fungsi jabatan CIO dalam kelembagaan TIK adalah mengoordinasi, mengomunikasikan, dan mengevaluasi strategi pengembangan TIK bagi seluruh kepentingan OPD, serta dapat menjamin pelaksanaan/strategi pengembangan TIK secara selaras dan sinergis, sesuai dengan semangat reformasi birokrasi yang lebih efisien dan efektif.

Jabatan CIO dalam kelembagaan mempunyai tiga kelompok kompetensi, yaitu kompetensi teknis (penguasaan hardware dan software dan penyesuaian terhadap teknologi baru), kompetensi manajemen TIK yang mencakup pengembangan pengetahuan dan keterampilan dalam manajemen teknologi informasi, serta kompetensi koordinasi dalam pengambilan keputusan terutama dalam meningkatkan koordinasi antar OPD.

Sedangkan untuk menjamin efektivitas strategi dan efisiensi operasional pada pemerintahan harus dibangun IT governance yang terpola, bagaimana perencanaan, keputusan dan pengawasan/evaluasi dapat diimplementasikan oleh seorang CIO, sehingga penggunaan sarana dan prasarana TIK dapat didayagunakan secara optimal.

\section{Saran}

Peran dan fungsi jabatan CIO sebagai sector leading diimplementasikan dalam suatu kelembagaan TIK, sehingga optimalisasi tugas dibidang TIK pada satuan kerja di organisasi perangkat daerah (OPD) dapat terlaksana secara terkoordinatif dan sinergis.

Agar sumber daya manusia dibidang TIK lebih kompeten dan mempunyai konsep tata kelola (frame work) yang baik, hendaknya seorang pimpinan dalam kelembagaan TIK (CIO) sering melakukan pembinaan secara kontinyu dan terintegrasi kepada seluruh pegawai yang menangani bidang TIK, sehingga diperoleh suatu pemahaman literasi yang komprehensif.

\section{DAFTAR PUSTAKA}

Dwiyanto, Agus (Editor). (2005) Mewujudkan Good Governance Melalui Pelayanan Publik. Yogyakarta : Gadjah Mada. University Press.

Darono, Agung. (2011) Chief Information Officer Dalam Aktualisasi Manajemen Strategi, Jurnal Aplikasi Teknologi Informasi, Program Magister TI. Yogyakarta: Universitas Gajah Mada.

Gluck, F.W., S.P, Kaufman dan AS Walleck. (1999) The Four Phases of Strategic Management. Journal Business Strategy No 3. PP.417

Hariwijaya ,M. (2007) Metodologi dan Teknik Penulisan Skripsi, Tesis, dan Disertasi. Yogyakarta: Elmatera Publishing.

Indrajit, Richardus Eko. (2006) Electronic Government. Yogyakarta: Penerbit Andi.

IBM Institute for Business Value. (2009) Insight From The Global CIO Study. IBM Gobal Business Services. 
Nupikso. Daru. (2010) 15 (lima belas) Kumpulan Karya Tulis Temu Ilmiah Peneliti II, Bidang Teknologi Informatika dan Komunikasi Tahun 2010. Bandung.

Panduan Umum Tata Kelola TIK Nasional. Versi 1. (2007).

Supangkat, Suhono Harso. (2008) CIO, Peran Kepemimpinan Pengelola Informasi Untuk Pertumbuhan Organisasi, Cetakan Pertama. Bandung: ICT Institute STIE ITB.

Wheelen. Thomas L. dan J. David Hunger. (2004) Strategic Business and Business . $9^{\text {th }}$ Edition. Pearson Education Management.

Wim Van Grembergen. (2004) Strategies for Information Technology Governance, Idea Group Inc.

\section{Jurnal:}

Ardianto,Elvinaro. (2010) Advertorial Corporate Social Responsibility (CSR) di Media Massa Cetak. Jurnal Penelitian Komunikasi, Majalah Ilmiah
Vol 13 No. 2 . Balai Pengkajian dan Pengembangan Komunikasi dan Informatika Bandung.

\section{Internet:}

Eko Prasojo, (2012) Sistem Manajemen Kebijakan Publik, Wakil Menteri Pemberdayaan Aparatur Negara dan Reformasi Birokrasi, tersedia dalam: $<$ http://www.ekoprasojo.com/2012/07/ 261>, diakses tanggal 5 Agustus 2012.

Rozas, Indri Sudanawati. (2012) Frame Work Tata Kelola IT, tersedia dalam: $<$ http://www.indrisudanawati.dosen.nar otama.ac.id $>$. diakses tanggal 10 Agustus 2012. http://passriograzio.blogspot.com

Kumoro, Wahyudi. Kegagalan Penerapan eGovernment dan Kegiatan Tidak Produktif dengan Internet. Tersedia dalam

$<$ http://kumoro.staff.ugm.ac.id/op cont ent/uploads/2009. http://unapcid.org/bahasa.../academygraduate 3-bahasa ID-pdf. http://ibenkda.blogspot.com/2008/03/ci o-pemda.htm/ 